DOI https://doi.org/10.15589/znp2021.2(485).7

UDC 005.8:519.876.5

\title{
ECONOMIC AND MATHEMATICAL MODEL OF AN INVESTMENT ECO-PROJECT UNDER CONDITIONS OF UNCERTAINTY
}

\section{ЕКОНОМІКО-МАТЕМАТИЧНА МОДЕЛЬ ІНВЕСТИЦЙНОГО ЕКОПРОЄКТУ В УМОВАХ НЕВИЗНАЧЕНОСТІ}

\author{
Olga V. Tsesliv ${ }^{1}$ \\ ceslivolga@gmail.com \\ ORCID: 0000-0002-8190-2502 \\ Anna S. Kolomiiets ${ }^{2}$ \\ kolomietsa@fit.knu.ua \\ ORCID: 0000-0003-4252-5975 \\ Serhii V. Kolomiiets ${ }^{3}$ \\ s.kolomiiets@ntu.edu.ua \\ ORCID: 0000-0001-9825-8904
}

\author{
О. В. Цеслів ${ }^{1}$, \\ канд. техн. наук, доцент \\ А. С. Коломісць ${ }^{2}$, \\ канд. екон. наук., доцент \\ С. В. Коломісць ${ }^{3}$, \\ канд. техн. наук, доцент
}

\author{
${ }^{1}$ National Technical University of Ukraine “Igor Sikorsky Kyiv Polytechnic Institute”, Kyiv \\ Національний технічний університет України «Київський політехнічний інститут імені Ігоря Сікорського», м. Київ \\ ${ }^{2}$ Taras Shevchenko National University of Kyiv, Kyiv \\ Київський національний університет імені Тараса Шевченка, м. Київ \\ ${ }^{3}$ National Transport University, Kyiv \\ Національний транспортний університет, м. Київ
}

\begin{abstract}
This article is devoted to the development of an economic and mathematical model for evaluating the effectiveness of startup projects in of ecology, based on simulation modeling. Startups are small companies that build their business on the latest innovative ideas using modern information technologies and are characterized by high risk.

Simulation modeling is a method of analyzing and synthesizing complex systems that is used when traditional mathematical research methods are impossible or ineffective. It is interesting to study the risk in simulation modeling. The paper considers two investment projects in the ecology. The study is conducted on the basis of net present value and internal profitability. Vectors of $\mathrm{N}$ random numbers with a uniform distribution law and interval boundary points are generated. The calculation was performed in the Mathcad program. The risk ratio for the projects under consideration is calculated. A histogram of the NPV distribution is plotted. As a result of a qualitative analysis, the project factors that are most at risk were identified. The rating of project factors is determined.

The development of an investment project is based on certain principles, and the analysis of project risks plays an important role. The current economic situation is characterized by instability, which must be taken into account in the process of making competent investment and design decisions.

However, for an adequate risk assessment, it is necessary to have a sufficient amount of data, which is sometimes impossible to obtain. If physical data is difficult or impossible to obtain, they are replaced with values obtained during the simulation experiment.

The novelty of the work is the definition of the risk coefficient as a ratio of expected values: unfavorable and favorable deviations of indicators from the predicted level. The paper finds risk coefficients for two of the studied ecoprojects. Qualitative analysis was performed in EXCEL, namely the sensitivity of the NPV to project risk factors.

The model can be used by both investors and entrepreneurs.
\end{abstract}

Key words: net present value; risk factor; simulation; discounting; qualitative analysis.

Анотація. Стаття присвячена розробці економіко-математичної моделі оцінки ефективності стартап-проєктів у сфері екології на основі імітаційного моделювання. Стартапи - це невеликі компанії, які будують свій бізнес на новітніх інноваційних ідеях з використанням сучасних інформаційних технологій та характеризуються високим ризиком. 


\section{КОМП'ЮТЕРНІ НАУКИ ТА ІНФОРМАЦІЙНІ ТЕХНОЛОГІЇ №2ロ 2021}

Імітаційне моделювання - це метод аналізу і синтезу складних систем, який використовується, коли традиційні математичні методи дослідження неможливі або неефективні. Цікавим є дослідження ризику в імітаційному моделюванні.

У роботі розглянуто два інвестиційні проєкти у сфері екології. Дослідження проводилося на основі чистої приведеної вартості та внутрішньої прибутковості. Генеруються вектори з $\mathrm{N}$ випадкових чисел з рівномірним законом розподілу та граничними точками інтервалу. Розрахунок проведено в програмі Mathcad. Розраховано коефіцієнт ризику для розглянутих проєктів. Побудовано гістограму розподілу NPV. В результаті якісного аналізу були виявлені фактори проєкту, найбільш схильні до ризику. Визначено рейтинг чинників проєкту.

Розробка інвестиційного проєкту базується на певних принципах, при цьому важливу роль відіграє аналіз проєктних ризиків. Сучасна економічна ситуація характеризується нестабільністю, що необхідно враховувати в процесі прийняття грамотних інвестиційно-проєктних рішень.

Однак для адекватної оцінки ризику необхідно мати достатню кількість даних, отримати які деколи неможливо. Якщо фізичні дані отримати важко або неможливо, їх замінюють величинами, що були отримані під час імітаційного експерименту.

Новизною роботи $є$ визначення коефіцієнту ризику як співвідношення сподіваних величин - несприятливих і сприятливих відхилень показників від прогнозованого рівня. У роботі знайдено коефіцієнти ризику для двох досліджуваних екопроєктів.

Якісний аналіз був проведений в програмі EXCEL. Аналізувалась чутливість NPV до чинників проєкту, схильних до ризику.

Модель може бути використана як інвесторами, так і підприємцями.

Ключові слова: чиста приведена вартість; коефіцієнт ризику; імітаційне моделювання; дисконтування; якісний аналіз.

\section{PROBLEM STATEMENT AND ANALYSIS OF THE LITERATURE}

One of the methods for evaluating the effectiveness of an investment is simulation modeling. Simulation modeling is one of the most common methods of analyzing economic systems.

When solving firm management problems, the following methods are most often used: simulation modeling (29\%); linear programming (21\%); network planning and management methods (14\%); inventory management theory $(12 \%)$; nonlinear programming $(8 \%)$; dynamic programming $(4 \%)$; integer programming $(3 \%)$; queue theory (queuing systems) $(3 \%)$; others $(6 \%)$.

The issues of evaluating the effectiveness of startups are not sufficiently developed, and it is not always possible to use classical analytical methods, especially for problems with uncertainty. Issues of research of innovative development of enterprises were dealt with by such scientists as: Takha, Hemdi A. [1], Onikienko, S. V. [2], Yastremska, O. M. [3].

Methods designed to analyze the effectiveness of startup projects have been studied in a significant number of literature sources [4-7]. In previous works [8], economic and mathematical models constructed using fuzzy sets are worked out, in which fuzzy variables are constructed that reflect uncertainty. Scientific research on the development of economic and mathematical models for analyzing the effectiveness of startups in ecology in conditions of uncertainty requires some improvement.

\section{THE AIM OF THE STUDY}

This section examines the possibilities of using the tools of economic and mathematical modeling in the course of making investment and design decisions in conditions of uncertainty. The aim of the study is to identify the main characteristics of uncertainty in order to adapt classical methods of risk analysis to it.

\section{METHODS, OBJECT AND SUBJECT OF RESEARCH}

Let's consider a methodology for assessing the risk of an investment ecoproject using simulation analysis. Simulation refers to conducting tests on a computer with mathematical models of real systems. Simulation modeling is based on game theory and is a series of numerical experiments that can be used to obtain an empirical estimate of the degree of influence of various factors on some results that depend on them.

Simulation modeling performs an empirical assessment of the degree of influence of the initial values on the results that depend on them. Numerical values of stochastic parameters for each experiment are taken as random numbers from confidence ranges of values. Confidence range is the range limited by the optimistic and pessimistic value of the parameter.

The simulation method includes the following four consecutive steps: primary information analysis; influencing factors identification; significant factors selection; determining the base value and range of changes for each selected factor.

We will conduct a project study based on net present value and internal profitability. Net present value $N P V$ is the difference between the present cash income and the amount of initial expenses (1):

$$
N P V=-I+\sum_{k=1}^{n} \frac{C F_{k}}{(1+r)^{k}},
$$


Where

$$
C F_{k}=\left[Q_{k}\left(P_{k}-V_{k}\right)-F-A\right](1-T)+A
$$

$Q_{k}$ - quantity of products sold; $P_{k}-$ unit price; $V_{k}-$ unit costs.

The net flow of payments includes profit from production activities and depreciation charges as income, and investments in capital construction, reproduction of fixed assets that are disposed of during the production period, as well as the creation and accumulation of working capital as expenses.

The discount multiplier $\frac{1}{(1+r)^{k}}$ recalculates the $N P V$ value after $k$ years. The discount rate is one of the most important tools that allows conducting an expert examination of the project, taking into account the risk present in it, as well as comparing various investment projects.

Since the $N P V$ includes random factors, the $N P V$ is also a random variable. Then you need to find its mathematical expectation $M(N P V)$ ) and standard deviation $\sigma_{N P V}$. Let's denote: $\mathrm{X}$ - is the NPV value, and $\mathrm{p}$ is the implementation probability. Then we determine the mathematical expectation of the $N P V$ by the formula:

$$
\begin{gathered}
M(N P V)=\sum x_{i} p_{i} ; \\
D(N P V)=\sum x^{2}{ }_{i} p_{i}-(M(N P V))^{2} ; \\
\sigma(N P V)=\sqrt{D(N P V)}
\end{gathered}
$$

In this paper, a sensitivity analysis is performed, consistently changing variables with respect to the baseline level of all risk variables. Sensitivity analysis has significant drawbacks. For example, the NPV of investment projects is always sensitive to changes in

variable costs and sales prices. However, if the company has signed a contract for the supply of a fixed volume of goods at a fixed price, this project can be quite safe.

That is, the NPV depends not only on changes in the values of input variables but also on the interval of probable values of these variables, which is determined by their probabilistic distribution.

In practice, all variables affect project results simultaneously, impairing or improving the resulting net present value of the project. Therefore, the next step in risk analysis is to analyze scenarios, which, based on the forecast of the probability of occurrence of the basic, pessimistic or optimistic scenario, will show the possibility of implementing this project.

The scenario approach associated with the development of project development options is already a multi-factor analysis that takes into account the interdependence of risk factors. It is important that the initial information about uncertainty factors can be converted into information about the possibility of implementing each scenario. In this case, the sum of the probability for all the proposed options should be equal to one.

The project management process is aimed at reducing the possibility of risky losses of the project during implementation, which is impossible without additional costs. The consequence of this is an increase in the cost of the project as a whole.

The study presents the main methods of project risk analysis, adapts classical methods of risk analysis to conditions of uncertainty, analyzes the possibilities of applying a number of non-traditional approaches to

\begin{tabular}{|c|c|c|c|c|}
\hline \multicolumn{3}{|c|}{ The first project } & \multicolumn{2}{|c|}{ The second project } \\
\hline & Minimum & Maximum & Minimum & Maximum \\
\hline Costs per unit (V) UAH & 320 & 500 & 400 & 600 \\
\hline Number of sold products (Q) pieces & 240 & 500 & 400 & 600 \\
\hline Price per unit $(\mathrm{P}) \mathrm{UAH}$ & 480 & 720 & 480 & 720 \\
\hline Initial investment (I) UAH & & 10000 & & 20000 \\
\hline Fixed costs $(\mathrm{F}) \mathrm{UAH}$ & & 1000 & & 2000 \\
\hline Amortization (A) UAH & & 500 & & 500 \\
\hline Discount rate $(\mathrm{r})$ & & 0,1 & & 0,1 \\
\hline Taxes $(\mathrm{T}), \%$ & & 60 & & 60 \\
\hline Project implementation period, years & & 5 & & 5 \\
\hline
\end{tabular}
risk analysis and methods of economic and mathematical modeling for non-stationary conditions.

Table 1. Calculation of key parameters

Table 2. The results of the calculation

\begin{tabular}{|c|c|c|}
\hline & The first project & The second project \\
\hline $\max (N P V)$ UAH & 268700 & 225300 \\
\hline $\min (N P V)$ UAH & -15740 & -108300 \\
\hline Mathematical expectation NPV UAH & 93060 & 54480 \\
\hline Standard deviation NPV UAH & 56870 & 70990 \\
\hline Investment project risk & 0,051 & 0,221 \\
\hline CV & 0,611 & 1.303 \\
\hline
\end{tabular}




\section{КОМП'ЮТЕРНІ НАУКИ ТА ІНФОРМАЦІЙНІ ТЕХНОЛОГІЇ №2ロ 2021}

\section{THE MAIN MATERIAL AND DISCUSSION OF THE RESULTS}

The firm is considering two investment projects for the production of ecoroducts A and B, respectively. Table 1 sets the key parameters for calculating investment projects. Key project parameters and limits of their changes are defined (table 1).

We generate vectors from $N$ random numbers that have a uniform distribution law, in which $b$ and $a$ are the boundary points of the interval $(a<b)$, using the Mathcad runif program function $(m, a, b) . \mathrm{N}$ is the number of imitations.

$$
\begin{gathered}
V_{k}=\operatorname{runif}\left(N, V_{\min }, V_{\max }\right) ; \quad Q_{k}=\operatorname{runif}\left(N, Q_{\min }, Q_{\max }\right) ; \\
P_{k}=\operatorname{runif}\left(N, P_{\min }, P_{\max }\right) ; \quad I_{k}=\operatorname{runif}\left(N, I_{\min }, I_{\max }\right) \\
C F_{k}=\left[Q_{k}\left(P_{k}-V_{k}\right)-F-A\right](1-T)+A \\
N P V_{k}=p v\left(r, n,-\left(C F_{k}\right)\right)-I_{k} ;
\end{gathered}
$$

Determine

$$
R 1=\max (N P V)-\min (N P V)
$$

$S 1=\sum_{k}$ if $\left(N P V_{k}<0, N P V_{k}, 0\right) S 2=\sum_{k} i f\left(N P V_{k} \geq 0, N P V_{k}, 0\right)$

Let's calculate the risk coefficient $\left(K_{\text {risk }}\right)$, determined by the formula:

$$
K_{\text {risk }}=\frac{\left|S_{1}\right|}{\left|S_{1}\right|+\left|S_{2}\right|}
$$

The risk coefficient generally shows the ratio of expected values of unfavorable and favorable deviations of indicators from the predicted level. For our projects $K_{\text {risk } 1}=0,003, K_{\text {risk } 2}=0,134$.

Let's analyze the results obtained (Table 2). In our case, the risk ratio (Krisk) for the first project is less. The calculation results are shown in Table 2.

The risk ratio values can vary from zero to infinity. That is, when there is almost no risk, the value of the risk ratio approaches zero; the greater the risk value, the greater the risk ratio.

To assign the resulting level of risk to one of the risk zones, you can use the risk scale (Table 3).

Table 3. Risk gradation

\begin{tabular}{|c|c|}
\hline Risk factor & Risk gradation \\
\hline $0-0,25$ & Low risk \\
\hline $0,25-0,75$ & Medium risk \\
\hline 0,75 and above & High risk \\
\hline
\end{tabular}

Let's calculate the mathematical expectation of the NPV: mean (NPV1). Let's calculate the standard deviation of the NPV: Stdev $(N P V 1)$.

Let's plot a histogram of the NPV distribution:

$$
H=\operatorname{histogram}\left(\frac{N}{50}, N P V 1\right)
$$

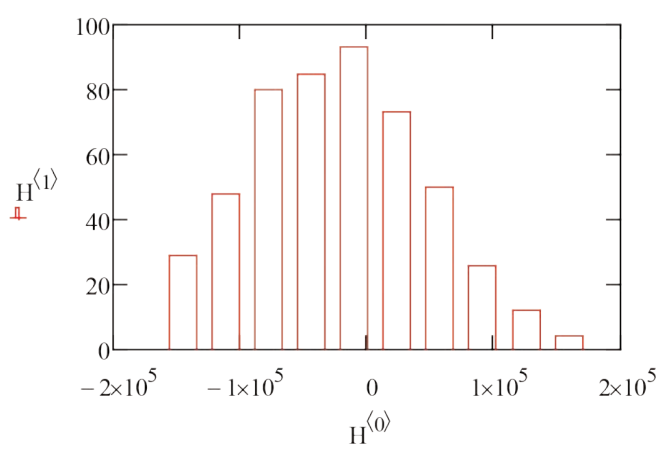

Fig. 1. NPV distribution histogram

Since the $N P V$ has a normal distribution, the risk of an investment project is calculated as follows:

$$
R=\operatorname{pnorm}(0, \text { mean Stdev }(N P V 1))
$$

Analyzing the results in Table 2, we see that the first option is less risky. Risk of investment projects: $\mathrm{R}_{1}=0,047, \mathrm{R}_{2}=0,221$.

We will use standard methods for calculating the $N P V$ and find pessimistic, basic, and optimistic scenarios. As a result of conducting a qualitative analysis in EXCEL, project factors that are at risk were identified.

Sensitivity analysis is a standard method that consists of substituting various hypothetical values of critical parameters into the financial model of the project and then calculating them. It is assumed that these parameters will decrease by $10-50 \%$ and increase by $10-40 \%$. After that, the «threshold» beyond which the project will not pay off is calculated mathematically.

The results of the sensitivity analysis are shown in Table 4, and the rating factors of the project that affect the risk and their rating are also determined.

Project analysis suggests that a second project with a more sensitive $N P V$ is considered riskier (Table 4).

The NPV is calculated for these variables and then compared with the expected base NPV value. In other words, the $N P V$ is calculated based on pessimistic, optimistic, and baseline scenarios (Table 5).

Table 4. Determining the rating of project factors influencing the risk

\begin{tabular}{|c|c|c|c|c|}
\hline Variable & Change variable, $\%$ & NPV change, $\%$ & Place in the ranking & Importance for the project \\
\hline V & 10 & 50 & 3 & very high \\
\hline Q & 10 & 37 & 2 & very high \\
\hline P & 10 & 42 & 1 & average \\
\hline I & 50 & 21 & 5 & average \\
\hline F & 50 & 10 & 4 & average \\
\hline
\end{tabular}


Table 5. The calculation of NPV for the three scenarios for the first startup

\begin{tabular}{|c|c|c|c|}
\hline Implementation scenario & Changing parameters & $\begin{array}{c}\text { The value of NPV } \\
\text { UAH }\end{array}$ & $\begin{array}{c}\text { The probability } \\
\text { of realization }\end{array}$ \\
\hline Pessimistic & Decrease in prices and sales volume by 20\% & 47847,41 & 0,3 \\
\hline Basic & & 80599,8 & 0,6 \\
\hline Optimistic & The increase in prices and sales volume by 20\% & 120630,5 & 0,1 \\
\hline
\end{tabular}

Table 6. Calculation of NPV for three scenarios for the second startup

\begin{tabular}{|c|c|c|c|}
\hline Implementation scenario & Changing parameters & $\begin{array}{c}\text { The value of NPV } \\
\text { UAH }\end{array}$ & $\begin{array}{c}\text { The probability } \\
\text { of realization }\end{array}$ \\
\hline Pessimistic & Decrease in prices and sales volume by $20 \%$ & 26626,68 & 0,3 \\
\hline Basic & & 53920,34 & 0,6 \\
\hline Optimistic & The increase in prices and sales volume by 20\% & 87279,27 & 0,1 \\
\hline
\end{tabular}

Table 7. Indicators of calculations

\begin{tabular}{|c|c|c|}
\hline Indicators of variation & Value for the project 1, UAH & Value for the project 2, UAH \\
\hline Mathematical expectation & 74777 & 49068,14 \\
\hline Dispersion & 21169 & 17641,46 \\
\hline Averagelinear deviation & 25069,73 & 20891,45 \\
\hline The standard deviation & 36452,15 & 30376,8 \\
\hline
\end{tabular}

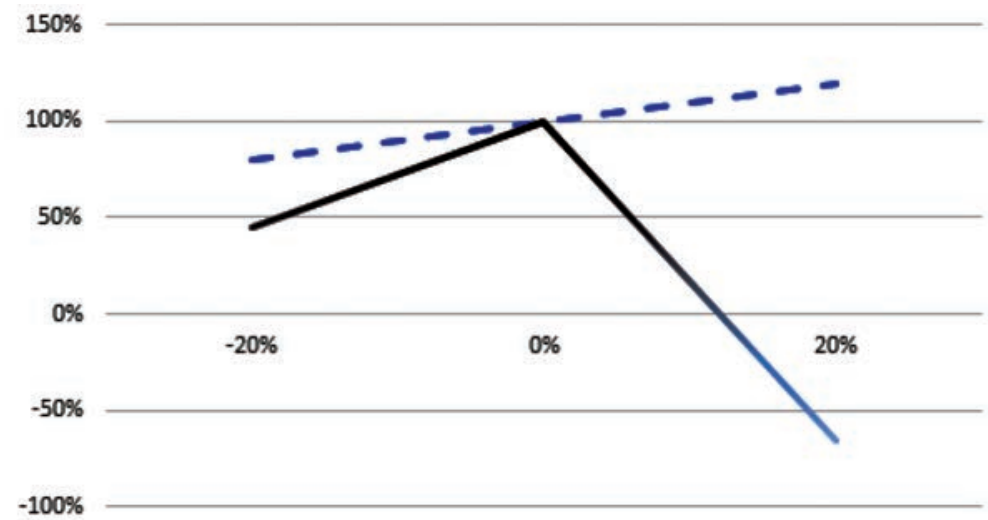

- Deviation of project factors - Deviation of NPV

Fig. 2. NPV sensitivity to project metrics

The results of scenario analysis can be used to determine the mathematical expectation of $N P V$, standard deviation, and variation.

The degree of influence of critical factors on the final efficiency can be demonstrated in Figure 2, which reflects the impact of the sales price, production cost, and physical sales volume on the result.

Currently, simulation modeling is the basis for creating new promising management and decision-making technologies in the business sector, and the development of computer technology and software makes this method increasingly accessible to a wide range of practitioners. The presented simulation model allows making decisions on estimating uncertainty. Based on the given simulation results, it is possible to determine the probability of the $N P V$.

\section{CONCLUSIONS}

The paper develops an economic and mathematical model for evaluating the effectiveness of startup projects in ecology, based on simulation modeling. The analysis of approaches and methods used to analyze project risks is carried out.

Two investment projects with different conditions were considered. The study is conducted on the basis of net present value and internal profitability. Vectors are generated for unit costs $(\mathrm{V})$, quantity of products sold $(Q)$, and unit prices $(P)$. Vectors consist of $N$ random numbers with a uniform distribution law and boundary points of the interval. The calculation was performed in the Mathcad program. The calculated risk ratio for the first and second projects. A histogram of the $N P V$ distribution 


\section{КОМП'ЮТЕРНІ НАУКИ ТА ІНФОРМАЦІЙНІ ТЕХНОЛОГІЇ №2 2021}

is plotted. As a result of a qualitative analysis, the project factors that are most at risk were identified. The rating of project factors is determined. $N P V$ is calculated for these variables and then compared with the expected base $N P V$ value. In other words, the $N P V$ is calculated based on pessimistic, optimistic, and baseline scenarios (Table 5).

The scenario analysis performed is a fairly advanced tool for assessing the own risk of an investment project, but it is not without drawbacks. Its limitation lies in the fact that only a few discrete values of project results are considered, while in reality these values can be infinitely many.

Sufficient data should be available for an adequate risk assessment. If physical data is difficult or impossible to obtain, they are replaced with values obtained during the simulation experiment.

All the considered performance indicators of the investment process are strongly linked. This is because they are all built on the basis of discounting the payment flow. However, the investment process that is better in one indicator will not always be more effective in other indicators, since the prerequisites and features of calculating each indicator differ.

Due to differences in estimates of the investment process, which can be observed when using different performance indicators, the question arises about the preference of certain performance meters. The most common indicator of investment performance is the internal rate of return, and the next indicator is net present income. All other investment performance indicators are used much less frequently. At the same time, it should be noted that it is advisable to apply both of the above indicators simultaneously, since the internal rate of return can be considered as a qualitative indicator that characterizes the return on a unit of invested capital, and net present income is an absolute indicator that reflects the scale of the investment process and the income received.

In this paper, efficiency is evaluated by the value of the risk factor, which is calculated differently. In the first case, as a ratio of expected values: unfavorable and favorable deviations of indicators from the predicted level. In the second version, standard functions are used. The calculation results almost coincided. The paper finds risk coefficients for two of the studied projects.

Further, it is necessary to continue scientific research on the development of economic and mathematical models for analyzing the effectiveness of startups in conditions of uncertainty.

As a result of a qualitative analysis, risk factors were identified for the project.

The degree of influence of critical factors on the value of net present value $(N P V)$ is studied. The work can be useful for scientists and businessmen.

\section{REFERENCES}

[1] Taha H.A.(2019). Vvedeniye v issledovaniye operatsiy [Introduction to the study of operations]. M .: «Williams».

[2] Onikienko, S.V. (2001). Postaudyt investytsiynykh proektiv (2), pp. 99-103.

[3] Yastremska, O.M. (2004). Investytsiyna diyal'nist' promyslovykh pidpryyemstv: metodolohichni ta metodychni zasady [Investment activity of industrial enterprises: methodological and methodical principles] . H.: VD "INZHEK".

[4] Saliga, K.S. (2007). Teoretychni zasady otsinky efektyvnosti real'nykh investytsiy [Theoretical principles of evaluating the effectiveness of real investments]. GU "ZI-DMU".

[5] Serdyuk, T.V. (2002). Biznes-plan investytsiynoho proektu [Business plan of the investment project: textbook. way. for students. econ. Special]. Vinnytsia: VSTU.

[6] Skvortsov, I.B.(2003). [The effectiveness of the investment process: methodology, methods and practice]. L .: "Lviv Polytechnic".

[7] Tsesliv O.V., Kolomiiets A.S. (2020). Assessment of investment risks of startup projects by fuzzy modeling. Collection of scientific works of the National University of Shipbuilding named after Admiral Makarov, (1), pp. 113-118.

[8] Khrutba, V. O. et al. (2019). Peculiarities of Implementation of the Environmental Management System of Motor Transport Enterprises on the Urban Territories. Journal of Environmental Management and Tourism (5), pp. 1094-1104. ISSN 2068-7729.

[9] Kolomiiets, S., Kolomiiets, A. (2020). Integral Criterion of Environmental Safety as an Indicator of the Effectiveness of a Motor Transport Enterprise Management. Lecture Notes Computational Intelligence and Decision Making. Vol. 1246, pp. 341-356 (2021). https://doi.org/10.1007/978-3-030-54215-3

[10] Birman G. (2003). Ekonomicheskiy analiz investitsionnykh proyektov [Economic analysis of investment projects]. Moscow: Banks and Exchanges, UNITI.

[11] Kolomiiets, A., Morozov V. (2020). Investigation of optimization models in decisions making on integration of innovative projects. Lecture Notes Computational Intelligence and Decision Making. Vol. 1246, pp. 51-64.

[12] Blank I.A. (2017). Investitsionnyy menedzhment [Investment Management]. K.: MP "ITEM" LTD.

[13] Bondar M.I. (2008). Investytsiyna diyal'nist': metodyka ta orhanizatsiya obliku i kontrolyu [Investment activity: methods and organization of accounting and control: monograph]. K.: KNEU.

[14] Goncharov A.B. (2003). Investirovaniye [Investirovanie: uchebnoe posobie dlya samosto-yatelnogo izucheniya diksipliny]. Kh. : House "Inzhek".

[15] Gryneva V.M. (2007). Analytical support of investment management of the enterprise. H .: KhNEU.

[16] Ponomarenko V.S. (2000): Real investment of business entities: textbook. X. : View. HDEU. 


\section{BIBLIOGRAPHY}

[1] Таха Х.А. (2019) Введение в исследование операций, 6-е издание. М. : «Вильямс», 912 с.

[2] Онікієнко С.В. (2001) Постаудит інвестиційних проєктів. Фінанси Украӥни. № 1. С. 99-103.

[3] Ястремська О.М. (2004) Інвестииійна діяльність промислових підприємств: методологічні та методичні засади. Х. : ВД «ІНЖЕК», $488 \mathrm{c}$.

[4] Салига К.С. (2007) Теоретичні засади оичінки ефективності реальних інвестицій. Запоріжжя : ГУ «ЗІДМУ», 52 с.

[5] Сердюк Т.В.(2002) Бізнес-план інвестиційного проєкту : навч. посіб. для студ. екон. спец. Вінниця : ВДТУ, 135 с.

[6] Скворцов І.Б. (2003) Ефективність інвестиційного процеесу: методологія, методи $і$ практика. Л. : «Львівська політехніка», 311c.

[7] Цеслів О.В., Коломієць А.С. (2020). Оцінювання інвестиційних ризиків стартап-проєктів методом нечіткого моделювання. Збірник наукових праць національного університету кораблебудування імені адмірала Макарова, № 1. C. 113-118.

[8] Хрутьба B.O. (2019). Peculiarities of Implementation of the Environmental Management System of Motor Transport Enterprises on the Urban Territories. Journal of Environmental Management and Tourism, №5, C. 1094-1104. ISSN 2068-7729.

[9] Коломієць С.В., Коломієць А.С. (2020). Integral Criterion of Environmental Safety as an Indicator of the Effectiveness of a Motor Transport Enterprise Management. Lecture Notes Computational Intelligence and Decision Making. № 1246. C. 341-356 (2021). URL: https://doi.org/10.1007/978-3-030-54215-3.

[10] Бирман Г. (2003) Экономический анализ инвестиционных проектов. М. : Банки и биржи, ЮНИТИ, 632 с.

[11] Коломієць А.С., Морозов В.В. (2020). Investigation of optimization models in decisions making on integration of innovative projects. Lecture Notes Computational Intelligence and Decision Making. № 1246. C. 51-64.

[12] Бланк И.А. (2017) Инвестициионный менеджмент. К. : МП «ИТЕМ ЛТД», 448 с.

[13] Бондар M.І. (2008) Інвестищійна діяльність: методика та організація обліку $i$ контролю : монографія. К. : KHEУ, 253 c.

[14] Гончаров А.Б. (2003) Инвестирование : учебное пособие для самостоятельного изучения дисциплины. Х. : Изд. дом «Инжэк», 352 с.

[15] Гриньова В.М. (2007) Аналітичне забезпечення управління інвестиційною діяльністю підприємства. Х. : ХНЕУ, 254 с.

[16] Пономаренко В.С. (2000) Реальне інвестування суб'єктів господарювання : навч. посіб. Х. : Вид. ХДЕУ, 168 с.

(C) Цеслів О. В., Коломієць А. С., Коломієць С. В.

Дата надходження статті до редакції: 11.06.2021

Дата затвердження статті до друку: 25.06.2021 